\title{
Pre-clinical test of dental Leucite glass-ceramics from local high grade silica sand: an in vitro study (cytotoxicity and genotoxicity)
}

\author{
Siti Mazatul Azwa Bt Saiyed Mohd Nurddin, Malek B Selamat \\ Pusat Penyelidikan Mineral, Jalan Sultan Azlan Shah, 31400 Ipoh, Perak \\ *Corresponding Author: sazwa@jmg.gov.my
}

Article history :

Received 19 November 2015

Accepted 08 December 2015

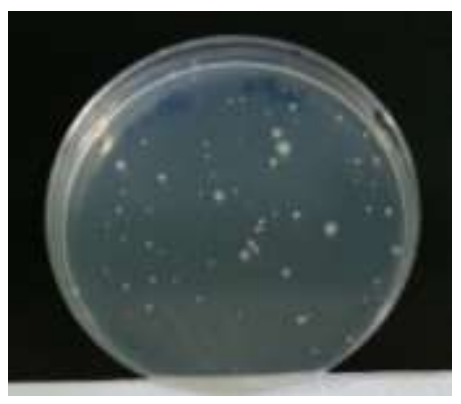

\begin{abstract}
The need for biocompatible of dental materials for use in restorative dentistry has generated a requirement for cytotoxicity and mutagenicity assays to screen compounds and characterize the potentially harmful effects of a material to oral tissues prior to clinical use. The objective of the study was to determine the degree of biocompatibility of leusite glass-ceramics that have been produced from local high grade silica sand in terms of cytotoxicity and mutagenicity assays. In the present study, the cyctotoxicity and mutagenicity were studied using the MTT and Ames Reverse Mutation. In the MTT assay, a dose response cytotoxicity of leucite sample was evaluated in L929 cells. The cells were treated with the concentrations of $6.25,12.5,25.0,50.00,100.00$ and $200.00 \mathrm{mg} / \mathrm{ml}$ of the leucite sample for 24 hours. The cytotoxicity was determined by assessing the cell viability through the reduction of tetrazolium salts (MTT). The mutagenenicity of leucite sample was evaluated in S. typhirium TA98. TA100, TA1535, TA1537 and E. coli WP2 in the Ames Reverse Mutation assay. Mutagenic effects were evaluated by comparing the mean number of revertant colonies of each extract concentraction with mean number of revertant colonies of the negative control. In results of MTT assay evaluated that the leucite did not show a cytotoxic effect at all concentrations under the condition of the study. Ames Reverse Mutation assay result proven that the leucite sample did not demonstrate a mutagenic effect under the condition of this study with Salmonella typhimurium and Escherichia coli.
\end{abstract}

Keywords: Ames Reverse Mutation assay, biocompatible, cytotoxicity, genotoxicity, MTT assay

(C) 2015 Penerbit UTM Press. All rights reserved http://dx.doi.org/10.11113/mjfas.v11n4.394

\section{INTRODUCTION}

Since the 1990s, efforts to develop biomaterials for restorative dentistry have been concentrated on producing metal-free systems. An important milestone in this respect was reached in the development of glassceramics containg leucite $\left(\mathrm{K}_{2} \mathrm{O}-\mathrm{Al}_{2} \mathrm{O}_{3}-\mathrm{SiO}_{2}\right.$ [1]. Glassceramics have been successfully used for many years in dentistry to construct crowns and fixed partial bridges due to the properties of high mechanical strength, chemical inertness, wear resistance, aesthetics and low density. Presently, leucite, mica and lithium disilicate glassceramics are widely used as restorative materials [2]. This material is particularly suitable for fabricating single units such as as dental inlays crowns and veneers because its special optical properties [3].

The biocompatibility is the most important issue for the application of medical ceramics whether biopassive, bioactive, or restorable ceramics. Medical ceramic materials often include glasses, glass-ceramics, and ceramic-polymer bioactive composite. The ceramics may be manufactured either in porous or in dense form of coating layers.
The biocompatibility is considered to be one of the most beneficial factors in using synthetic ceramics innovations in medicine. Any new glasses and glassceramics developed for medical purposes should posses this extremely important property of biological compatibility with living tissue.

A range of tests can be conducted to establish the biocompatibility of a biomaterial. These include in vitro test for cyctoxicity, microbial test to determine whether or not the material inhibits or stimulate the growth of microorganisms and genotoxicity/mutagenicity and carcinogenicity tests to assass possible systematic reactions [4].

Cyctotoxicity screening assays provide a measure of cell death caused by materials or their extracts. There are a vast number of cytotoxicity screening methods available for measuring the biocompatibility of a dental restorative material. .The application of different methods of cytotoxicity screening has been shown to produce a spectrum of biocompatibility assessment for the same material [5]. 
The identification of substances capable of inducing mutations has become an important procedure in safety assessment. Chemicals that can induce mutations

can potentially damage the germ line leading to fertility problems and to mutations in future generations. Mutagenic chemicals are also capable of inducing cancer, and this concern has driven most of the mutagenicity testing programs. Mutations can occur as gene (point) mutations, where only a single base is modified, or one or a relatively few bases are inserted or deleted, as large deletions or rearrangements of DNA, as chromosome breaks or rearrangements, or as gain or loss of whole chromosomes [6].

The Ames Salmonella test is used world-wide as an initial screen to determine the mutagenic potential of new chemicals and drugs. The test is also used for submission of data to regulatory agencies for registration or acceptance of many chemicals, including drugs and biocides. International guidelines have been developed for use by corporations and testing laboratories to ensure uniformity of testing [7].

\section{EXPERIMENTS}

Biomaterial. Local silica sand from Terengganu was used as one of the raw materials. The characterization of the silica sand was carried out using chemical analysis and X-ray fluorescence (XRF) analysis. Glass in the system of $\mathrm{SiO}_{2}-\mathrm{Al}_{2} \mathrm{O}_{3}-\mathrm{K}_{2} \mathrm{O}$ were prepared by melting the raw materials, quenched in deionizing water and dry milled to obtain glass powder. The powder was pressed and sintered to obtain glass-ceramics. Thermal analysis defined the crystallization of glass in the range of $650^{\circ} \mathrm{C}$ and $850^{\circ} \mathrm{C}$.

Cytotoxicity test on extracts. Cytotoxicity of the leucite glass-ceramics was evaluated by testing on extracts of leucite glass-ceramics according to ISO 109935:2009(E). Biological evaluation of medical devices-Part 5: Test for in vitro cytotoxicity and ISO 10993-12:2012(E). Biological evaluation of medical devices-Part 12: Sample preparation and reference material. American Type Culture Collection L-929 mouse subcutaneous connective tissue fibroblast cells (Mus musculus, NCTC clone 929, CCL-1) was used in this test. Cells at the 5 passages were employed. Zinc sulphate at $240 \mu \mathrm{g} / \mathrm{ml}$ and complete growth medium were used as the positive and negative control, respectively. L-929 cells were grown in tissues culture flasks using Minimum Essential Medium (MEM) as the growth medium at $37^{\circ} \mathrm{C}$ in a humidified atmosphere of $5 \%$ carbon dioxide and $95 \%$ air. Cultures were examined daily to ensure they remain healthy. Any changes in morphology or their adherent properties were noted. The confluent monolayer was removed by tripsinisation and the number of viable cells was calculated. Cells were seeded into a 96-well plate at seeding density 10000 cells/well and incubated at $37^{\circ} \mathrm{C}$ for at least 12 hours or until attaining
$80 \%$ confluency. The test material was extracted in a complete MEM at $200 \mathrm{mg} / \mathrm{ml}$. Extraction was carried out in water bath at $37^{\circ} \mathrm{C}$ for 24 hours with agitation. Prior to exposure, the extract was filter-sterilized using membrane

filtration method $(0.2 \mu \mathrm{m}$ pore size $)$. The test material was tested in triplicate at concentration of $6.25,12.5,25,50$, 100 and $200 \mathrm{mg} / \mathrm{ml}$. Growth medium from each well of a 96-well plate containing healthy culture was replaced with $200 \mu \mathrm{l}$ of the test material solution. The cultures were then incubated for 24 hours at $37^{\circ} \mathrm{C}$ in a humidified atmosphere of $5 \%$ carbon dioxide and $95 \%$ air.

Observation. Cellular response assessment: 3-(4,5dimethylthiazol -2-yl)-2,5-diphenyltetrazolium bromide (MTT) assay. Cellular response was assessed using MTT assay. MTT assay is based on the ability of mitochondrial dehydrogenase (SDH) enzyme from viable cells to cleave the tetrazolium rings of the pale yellow MTT and form dark blue formazan crystals, which is largely impermeable to cell membrane, thus resulting in its accumulation within viable cells. The number of viable cells is directly proportional to the level of the formazan product created [8]. MTT (Calbiochem, Germany) solution was prepared by dissolving $5 \mathrm{mg}$ of MTT powder in $1 \mathrm{ml}$ Phosphate Buffered Saline (PBS) and then filtering using $0.22 \mu \mathrm{m}$ syringe filter. Then, $20 \mu \mathrm{l}$ of the resulting MTT solution was added into each well and incubated for 4 hours at $37^{\circ} \mathrm{C}$ in a humidified atmosphere of of $5 \%$ carbon dioxide and $95 \%$ air. The media was removed after the incubation and $200 \mu$ l Dimethyl Sulfoxide (DMSO) (Sigma, France) was added to dissolve the blue formazan crystals. Optical densities of the resulting solutions were measured at 570 $\mathrm{nm}$ wavelength using absorbance measurement mode (Secomam, Prim Light, French).

Data analyses. Mean, standard deviation and percentage of cell viability were calculated. Percentage of cell viability was obtained by dividing the mean optical density (OD) values of the test material with the mean OD of negative control, and multiplied by 100 .

Ames Reverse Mutation Assay. The mutagenenicity of leucite glass-ceramic material for dental applications was evaluated in accordance with the requirements of Organisation for Economic Co-operation and Development (OECD) 471. The study provides early information on the mutagenicity potential of a material, substance or chemical. Salmonella typhirium strains TA98, TA100, TA1535, TA1537 and E. coli WP2 from Molecular Toxicology Inc. (MOLTOX). The test was conducted under 2 controls: i. without $\mathrm{S} 9$ metabolic activation that used $\mathrm{NaCl}$ solution (negative) and 4-nitro-o-phenylenediamine, sodium azide, methylmethanesulfonate, 9-aminoacridine (positive), ii. with $\mathrm{S} 9$ metabolic activation $\mathrm{NaCl}$ solution (negative) and 2-aminoanthracene (positive). All bacterial stock cultures are stored at $-80^{\circ} \mathrm{C}$.

Preparation of Bacterial Tester Strain Suspention. A $12 \mu \mathrm{l}$ amount of thawed stock culture was added to $12 \mathrm{ml}$ 
nutrient broth (Oxoid No. 2) in a conical flask and incubated at $4^{\circ} \mathrm{C}$ for seven hours. Cultures were then incubated at $37^{\circ} \mathrm{C}$ in a shaking water bath for $12-16$ hours.

Preparation of S9 mix (metabolic activation). The test material was mixed with $0.9 \% \mathrm{NaCl}$ solution to give a final concentration of $200 \mathrm{mg} / \mathrm{ml}$. The mixture was

incubated at $37^{\circ} \mathrm{C}$ for 24 hours in a shaking waterbath and was filter-sterilized using membrane filtration method (0.2 $\mu \mathrm{m}$ pore size) prior to use. Varying concentrations of test material extract were prepared to contain $3.13 \mathrm{mg} / \mathrm{ml}, 6.25$ $\mathrm{mg} / \mathrm{ml}, 12.5 \mathrm{mg} / \mathrm{ml}, 25 \mathrm{mg} / \mathrm{ml}$ and $50 \mathrm{mg} / \mathrm{ml}$ and were used immediately.

Exposure of Test Material to Cell Culture. The test material extract was tested in triplicate at $313 \mu \mathrm{g} / \mathrm{plate}$, $625 \mu \mathrm{g} /$ plate, $1250 \mu \mathrm{g} /$ plate $2500 \mu \mathrm{g} /$ plate and 5000 $\mu \mathrm{g} / \mathrm{plate}$ concentrations.

Pre-Incubation and Colony Counting. A $0.1 \mathrm{ml}$ amount of each concentration of test material was mixed with $0.5 \mathrm{ml}$ of buffer/S9 mix followed by the addition of $0.1 \mathrm{ml}$ each tester strain suspension. The mixture was shaken in a water bath for 20 minutes at $37^{\circ} \mathrm{C}$. Molten top agar enriched with a trace amount of histidine biotin or trypthopan was then overlaid on the surface of minimal glucose agar. After incubating at $37^{\circ} \mathrm{C}$ for 48 hours, revertant colonies in the test material plates were identified and counted. A comparison of test revertants with the number of spontaneous revertants in the negative control were made.

Observation. Mutagenicity was evaluated by comparing the number of mean number of revertant colonies produced at reach concentration of test extract with the mean number of colonies in the negative control. Revertant colonies were counted and the mean number for each dose was calculated. Positive results were indicative when the mean number of revertant colonies increased by twice or more than in the negative control. Positive results indicate the induction of mutation in the genome of Salmonella typhimurium and Escherichia coli.

Data Analysis. Mean and standard deviation of revertants were calculated. Positive results were indicative when the mean number of revertant colonies exceeded twice or more than the mean number of spontaneous revertants in the negative control. Positive results also indicate that the test material induces either frameshift mutation or base-pair substitution in the genome of Salmonella typhimurium and Escherichia coli.

\section{RESULTS AND DISCUSSION}

Cytotoxicity test. Cellular response assessment: 3-(4,5dimethylthiazol -2-yl)-2,5-diphenyltetrazolium bromide (MTT) assay. In this study, the MTT assay is used to evaluate the toxic characteristics of the leucite glassceramics and the yellow tetrazolium salt (MTT) is reduced in metabolically active cells to form insoluble purple formazan crystals which are solubilized by the addition of a solvent (dimethyl sulfoxide). Cell viability is qualified by

colorimetric enumeration whereby a low OD reading corresponds to low cell viability which is associated with a loss in mitochondrial dehydrogenase activity. The MTT test was proved to be more accurate and time saving than other conventional haemocytometer counting methods [10]. The study provides information on dose response curve and Inhibition Concentration (IC) of a test material.

The test material leusite glass-ceramics did not inhibit the viability of L929 cells at all concentrations following 24-hour treatment as shown in Table 1 and Figure 1.. Both negative and positive controls performed as anticipated. In MTT assay, the well with the highest absorbance indicates the highest cell viability.

Table 1 Optical density values and L929 cell viability obtained after 24-hour exposure to the test material leusite glass-ceramics

\begin{tabular}{|c|c|c|c|c|c|c|c|c|}
\hline & \multirow{2}{*}{$\begin{array}{l}\text { Negative } \\
\text { coittrol }\end{array}$} & \multirow{2}{*}{$\begin{array}{l}\text { Fositive } \\
\text { cortiol }\end{array}$} & \multicolumn{6}{|c|}{ Leucite gless-ceramics /meimili } \\
\hline & & & 6.25 & 12.5 & 25 & so & 100 & 200 \\
\hline$\infty 0$ & 1626 & 0561 & 1537 & 1656 & $13 / 4$ & 1357 & $14 \pi$ & $25 \% 6$ \\
\hline$\langle 570 \mathrm{em}\rangle$ & 1.674 & 0.551 & 1,696 & 1,582 & 1622 & 1.532 & 1.586 & : .355 \\
\hline & 162. & 0.516 & 1.603 & 1.477 & 1.522 & 1444 & 1000 & 2.496 \\
\hline Mean & 160 & 0.523 & 1.613 & $1.5 \% 3$ & 1.506 & 1515 & 2.336 & $2.4 \times 6$ \\
\hline 30 & 0.00 & 0.03 & $a, 08$ & 000 & Q.12 & 0.07 & 0.07 & a.11 \\
\hline Mablity & 100 & 32 & 98 & 96 . & 91 & 92 & 94 & 90 \\
\hline
\end{tabular}

In this study, American Type Culture Collection L-929 mouse subcutaneous connective tissue fibroblast cells (Mus musculus, NCTC clone 929, CCL-1) was used to assess the cyctotoxicity of the locally produced dental leucite glassceramics. The uses of these cell lines for cyctoxicity evaluation of biomaterials have been reported [9].

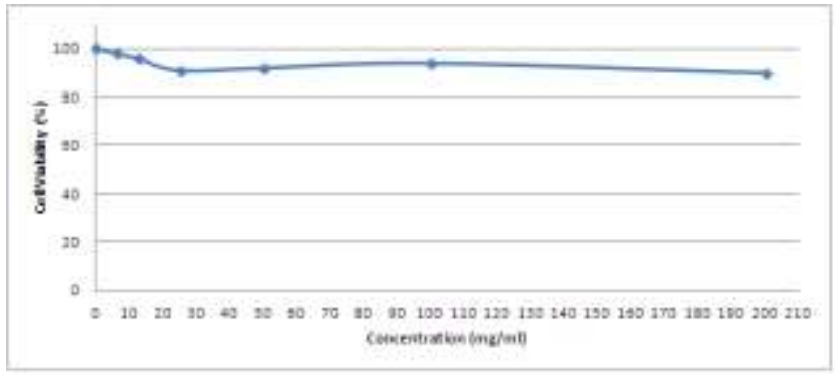

Figure.1 Viability of L929 cells at various concentrations of the test material leucite glass-ceramics

The toxicity of a material is mainly caused by either released ions and compounds or worn debris from metals, ceramics or polymers [11]. However, identifying the exact components in the dental materials that can cause the cytotoxicity effect is difficult, as also reported by Wataha et al. (1995) [12] who have debated on the 
difficulties in correlating cyctotoxicity with elements, released from the dental materials.

Ames Reverse Mutation Assay. In this test, the potential of the sample to cause a mutagenic effect in bacteria by comparing the number of revertant mutations in the bacterial tester strains and restore the fuctional capability of the bacteria to synthesize an essential amino

acid (histidine biotin or tryptophan) was determined. Revertant bacteria are recognized by their ability to grow in the absence of the amino acid.

The Salmonella and Escherichia coli.strains used in this test have different mutations in various genes in the histidine operon; each of these mutations is designed to be responsive to mutagens that act via different mechanisms. A mutagenic material will give rise to a ring of revertant colonies surrounding the area where the chemical. If a material is toxic, a zone of growth inhibition will also be observed [13]. Figure 2 depicts a spot test of Escherichia coli WP2 at $5000 \mu \mathrm{g} /$ plate concentration. When the histidine dependent bacteria are grown on a glucose minimal agar plate containing a trace amount of hisdine, only those cells that revert to histidine independence $\left(\mathrm{His}^{+}\right)$ are able to form colonies.

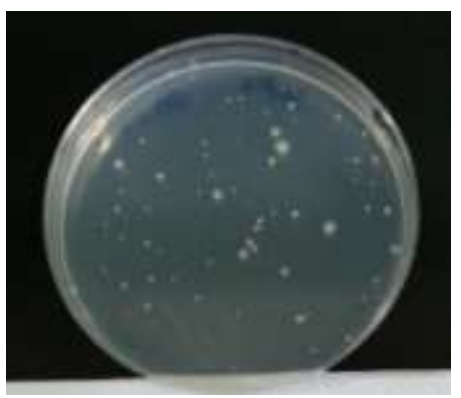

Figure. 2 Spot test with strain Escherichia coli WP2 at 5000 $\mu \mathrm{g} /$ plate concentration.

The test material leucite glass-ceramic extract was evaluated for its potential to induce gene mutation using the pre-incubation method. Results of the study are summarized in Table 1 to 5 indicating the mean number of revertants induced by varying test extract concentrations as well as the negative and positive control items.

Table 1 Revertant colonies of S. typhirium strains TA98 induced by the test extract in the absence and presence of metabolic activation ( $\mathrm{S} 9$ mix)

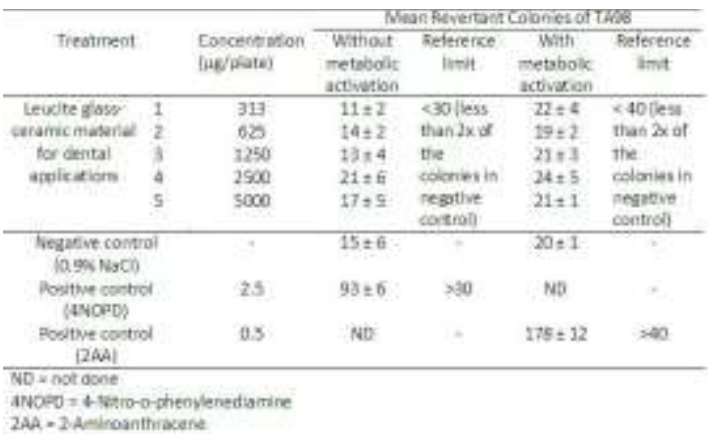

Table 2 Revertant colonies of S. typhirium strains TA 100 induced by the test extract in the absence and presence of metabolic activation ( $\mathrm{S} 9 \mathrm{mix}$ )

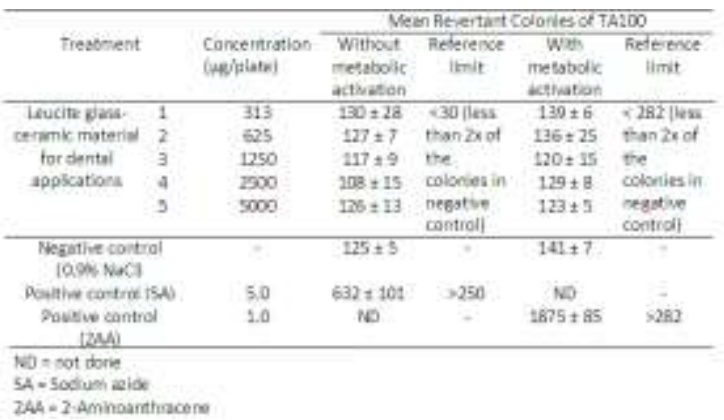

Table 3 Revertant colonies of S. typhirium strains TA 1535 induced by the test extract in the absence and presence of metabolic activation ( $\mathrm{S} 9 \mathrm{mix}$ )

\begin{tabular}{|c|c|c|c|c|c|c|}
\hline \multirow{2}{*}{\multicolumn{2}{|c|}{ Trostment }} & \multirow[b]{2}{*}{$\begin{array}{l}\text { Concectiation } \\
\text { lus/piate! }\end{array}$} & \multicolumn{4}{|c|}{ Nean Rever tant Cololies of ta15.5 } \\
\hline & & & $\begin{array}{l}\text { Without } \\
\text { menatoic } \\
\text { activation }\end{array}$ & $\begin{array}{l}\text { Heserence } \\
\text { linst }\end{array}$ & $\begin{array}{l}\text { With } \\
\text { metabolic } \\
\text { actoration }\end{array}$ & $\begin{array}{c}\text { Notarance } \\
\text { lesit }\end{array}$ \\
\hline Leucite goss:- & 1 & 353 & $9 \pm 2$ & $<22$ liess & $14 \pm 3$ & < 32 iless \\
\hline ceramic materio & 2 & a25. & $15=4$ & $\operatorname{tin} 2 x$ of & $27 \pm 3$ & then $2 \times$ of \\
\hline for dental & 3 & 1290 & $13: 4$ & the & $14 \div 2$ & \\
\hline \multirow[t]{2}{*}{ Apolicitons } & 4 & 2500 & $14=8$ & colocoles is & $23 \pm 1$ & colonias in \\
\hline & 5 & 5000 & $9=3$ & $\begin{array}{l}\text { negative } \\
\text { controd }\end{array}$ & $14 \pm 2$ & $\begin{array}{l}\text { regative } \\
\text { cortioli }\end{array}$ \\
\hline 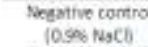 & & - & $11=2$ & + & $16 \div 1$ & 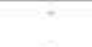 \\
\hline 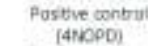 & & as & $273=7$ & $>22$ & No & - \\
\hline $\begin{array}{c}\text { Postive conbus } \\
[22 A]]\end{array}$ & & 2.0 & ND & - & $235+25$ & $>32$ \\
\hline
\end{tabular}

Table 4 Revertant colonies of S. typhirium strains TA 1537 induced by the test extract in the absence and presence of metabolic activation (S9 mix)

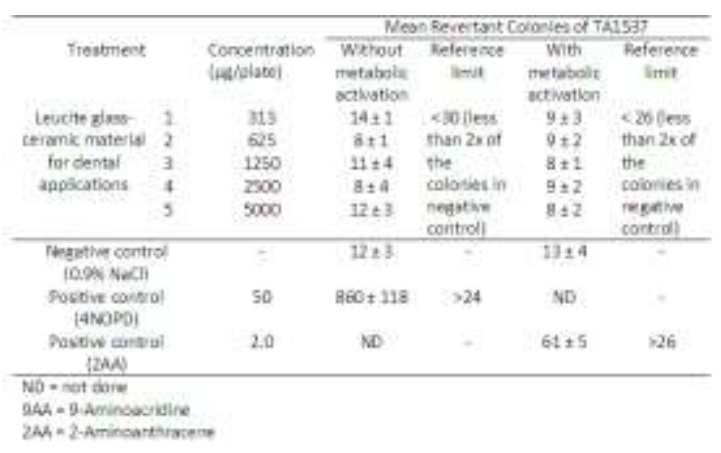


Table 5 Revertant colonies of $E$. coli strain WP2 (trp, uvrA, pKM101) induced by the test extract in the absence and presence of metabolic activation (S9 mix)

\begin{tabular}{|c|c|c|c|c|c|c|}
\hline \multirow{3}{*}{\multicolumn{2}{|c|}{ Tresonest }} & \multirow{3}{*}{$\begin{array}{l}\text { Corceitration } \\
\text { his/presel }\end{array}$} & \multirow{2}{*}{\multicolumn{4}{|c|}{ 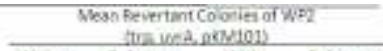 }} \\
\hline & & & & & & \\
\hline & & & \multirow{2}{*}{$\begin{array}{c}\text { Wisiout } \\
\text { ifataberic } \\
\text { exthetion } \\
82 \pm 4\end{array}$} & $\begin{array}{c}\text { Acfersence } \\
\text { Imt }\end{array}$ & \multirow{2}{*}{$\begin{array}{l}\text { With } \\
\text { matabik } \\
\text { exturion } \\
104=11\end{array}$} & \multirow{2}{*}{$\begin{array}{c}\text { Soltereice } \\
\text { lint }\end{array}$} \\
\hline Leuche glas & 2 & 313 & & colka & & \\
\hline ceramic nowial & 2 & 625 & $\pi \pm 5$ & than $2 x$ of & $108=11$ & $\operatorname{Dan} 2 \times$ of \\
\hline for dintel & 3 & 1250 & $75+2$ & & $120 \div 2$ & \\
\hline \multirow{2}{*}{\multicolumn{2}{|c|}{ applicatom }} & 2520 & $88+5$ & colseies in & $9 a+14$ & odenien it: \\
\hline & 5 & 5000 & $88 \pm 6$ & $\begin{array}{l}\text { negative } \\
\text { caribula }\end{array}$ & $219 \pm 3$ & $\begin{array}{l}\text { rejultive } \\
\text { sontrab }\end{array}$ \\
\hline \multicolumn{2}{|l|}{ 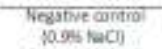 } & $=$ & $9=15$ & -1 & शान & 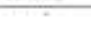 \\
\hline \multicolumn{2}{|l|}{$\begin{array}{l}\text { Atselive carival } \\
\text { Jenopol }\end{array}$} & 23 & $1976+250$ & $>178$ & Na. & $=$ \\
\hline \multicolumn{2}{|l|}{$\begin{array}{c}\text { monthe comal } \\
\text { D2SA }\end{array}$} & 0.5 & MD & $=$ & $2050=170$ & 2132 \\
\hline $\begin{array}{l}\text { No + not dose } \\
\text { NWes + Methyl me: }\end{array}$ & & & & & & \\
\hline $24 A=2$ Aninoast & & & & & & \\
\hline
\end{tabular}

Induction of revertants of Salmonella typhimurium and Escherichia coli tester strains treated with the test material extracts did not exceed twice the number of the negative control, either in the presence or absence of metabolic activation. However, a significant number of revertants were produced by the positive control items.

\section{CONCLUSION}

Terengganu silica sand deposits can be used as $\mathrm{SiO}_{2}$ source for producing leucite glass-ceramics for dental applications without any further chemical upgrading in order to improve the purity of the silica sand and get rid some of the impurities such as iron and alumina.

The cyctotoxicity test results showed that the test material leucite glass-ceramics did not demonstrate a cytotoxic effect at all concentrations under the condition of the study. The results obtained from the Ames Reverse Mutation Assay also showed that the leucite glass-ceramics did not demonstrate a mutagenic effect under the condition of this study with Samonella typhimurium and Escherichia coli strains. potential in terms of cellular response to L-929 mouse subcutaneous connective tissue fibroblast cell; and Salmonella typhirium strains TA98, TA100, TA1535, TA1537 and Escherichia coli WP2.

\section{ACKNOWLEDGEMENTS}

The authors would like to thank the Mr. Shahar Effendi Director of Mineral Research Centre Malaysia, Mrs. Rashita Abd. Rashid, Head of Advanced Material Section of Mineral Research Centre and all staff of Mineral Research Centre who were involved and had contributed in this research work.

\section{REFERENCES}

[1] V. Rheinberger, Perspectives in dental ceramics. Glastech Ber. Glass Sci. Technol., 70C (1997) 339-400

[2] M.J. Cattell, C. T. Knowles, R.L. Clarke, Dental Materials, 21 (2005) 811-822.

[3] Y.H. Huang, J.J. Wang, Z.M. Liu, G.D. Zhang, Appl. Catal. A 466 (2013) 300.

[4] G.S. Schuster, C.A. Lefebvre, J.C. Wataha, S.N. White, J. Calif. Dental Assoc. 24 (9) (1996) 17-31.

[5] F.B. Bagambisa, H.P. Kappert, W. Schili, J. Oral Maxillofac Surg. 52 (1) (1994) 52-56.

[6] I. L. Denry, Crit Rev Oral Biol Med. 7 (2) (1996) 134-143.

[7] F.M. Freimoser, C.A. Jakaob, M. Aebi, U. Tour, Appl. Environ. Microbiol. 65 (8) (1999) 3727-3729.

[8] D.J. Liu, Y. Hermansson, L. Soremark, In vitro. Clin. Mater. 12 (4) (1993) 197-201

[9] J.C. Wataha, J. Prosthet. Dent. 86 (2) (2001) 203-209.

[10] E. M. Peter, G.G. Cristina, G. G. Franklin, Med. Oral Patol. Oral Cir. Bucal. 12 (2007) E258-266

[11] A. Nel, T. Xia, L. Madler, N. Li, Science. 311 (2006) 622-627

[12] J.C. Wataha, P.E. Lockwood, Dent. Mater. 14 (20) (1995) 9-14 Karelovic, A.; Ruiz, P. ACS Catal. 3 (2013) 2799.

[13] M. Kristien, Z. Errol, Mutation Research. 455 (2000) 29-60
In conclusion, the locally produced leucite glassceramics is ranked non-cytotoxic and non-mutagenic 